3. Trimble MR, Robertson MM. Vocal tics in Gilles da la Tourette syndrome treated with botulinum toxin injections. Mov Disord 1998;13:617-619.

4. Salloway S, Stewart CF, Israeli L, et al. Botulinum toxin for refractory vocal tics. Mov Disord 1996;11:746-748.

5. Adler CH, Zimmerman RS, Lyons MK, Simeone F, Brin MF. Perioperative use of botulinum toxin for movement disorderinduced cervical spine disease. Mov Disord 1996;11:79-81.

6. Krauss JK, Jankovic J. Severe motor tics causing cervical myelopathy in Tourette's syndrome. Mov Disord 1996;11:563-566.

7. Jankovic J. Botulinum toxin in the treatment of dystonic tics. Mov Disord 1994;9:347-349.

8. Kwak CH, Hanna PA, Jankovic J. Botulinum toxin in the treatment of tics. Arch Neurol 2000;57:1190-1193.
9. Goetz CG, Tanner CM, Wilson RS, Shannon KM. A rating scales for Gilles de la Tourette's syndrome: description, reliability and validity data. Neurology 1987;37:1542-1544.

10. Harcherik DF, Leckman JF, Detlor J, Cohen DJ. A new instrument for clinical studies of Tourette's syndrome. J Am Acad Child Adolesc Psychiatry 1984;23:153-160.

11. Shapiro AK, Shapiro ES, Young YG, Feinberg TE, eds. Gilles de la Tourette syndrome. New York: Raven Press; 1988.

12. Leckman JF, Riddle MA, Hardin MT, et al. The Yale Global Tic Severity Scale: Initial testing of a clinician-rated scale of tic severity. J Am Acad Child Adolesc Psychiatry 1989;28:566-573.

13. Kurlan R, McDermott MP. Rating tic severity. In: Kurlan R, ed. Handbook of Tourette's syndrome and related tic and behavioral disorders. New York: Marcel Dekker; 1993:199-220.

\title{
Neuro/mages
}

\section{Leukoaraiosis three-dimensional in Binswanger disease}

Carlos Valencia, MD, Joan Martí-Fàbregas, MD, Jesús Pujol Nuez, MD, Josep-Lluis Martí-Vilalta, MD, Barcelona, Spain

An 81-year-old man had been hypertensive for years. Three years before this evaluation, he had a stroke and brain imaging showed a left putaminal infarct. During the last 2 years his gait, cognitive abilities, and behavior have gradually deteriorated. On examination, he walked with slow shuffling steps. His Mini-Mental State Examination score was 22. MRI showed severe white matter abnormalities characteristic of Binswanger disease. The white matter abnormalities (leukoaraiosis) in Binswanger disease are most likely caused by chronic ischemia. The most common clinical presentation consists of slowed thinking, walking, and behavior in an elder individual with hypertension.

\section{References}

1. Caplan LR. Binswanger's disease-revisited. Neurology 1995; 45:626-633.

2. Blass JP, Hoyer S, Nitsch R. A translation of Otto Binswanger's article: the delineation of the generalized progressive paralysis. Arch Neurol 1991;48:961-972.

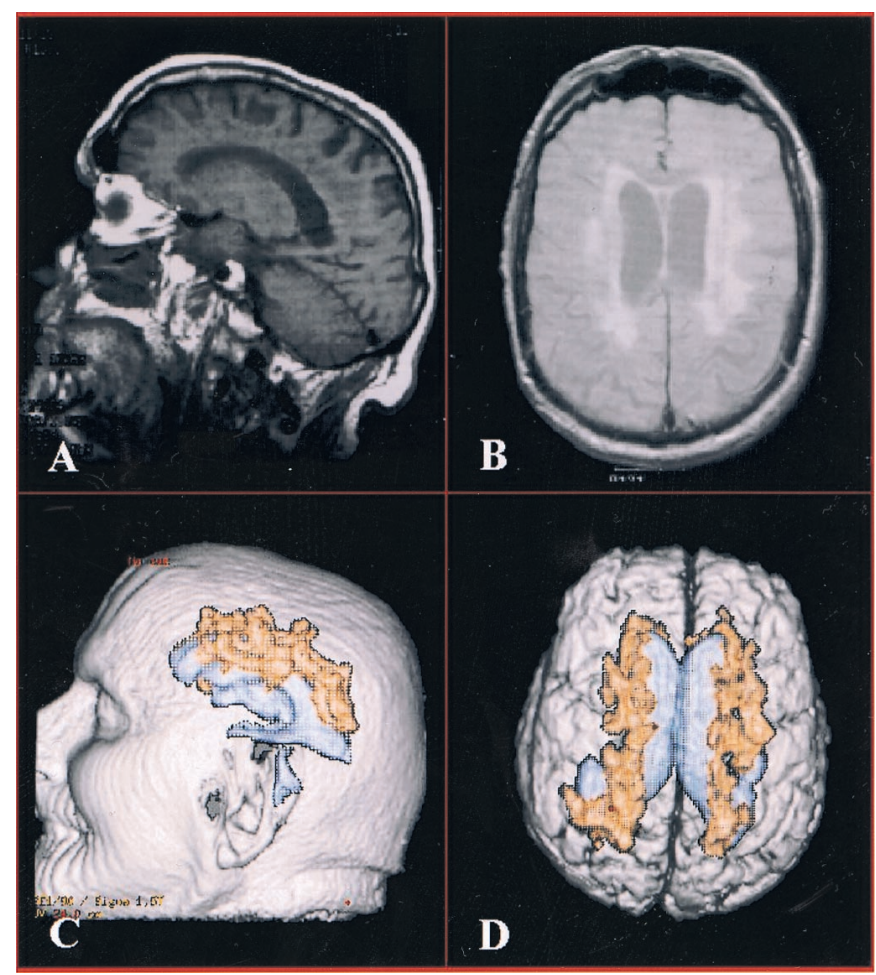

Figure. (A) On T1-weighted MRI, the white matter abnormalities are not well shown. Proton density images (B) show prominent white matter hyperintensities. $C$ and $D$ are three-dimensional images that show white matter lesions (light brown) located predominantly in the frontal and parietal lobes adjacent to the lateral ventricles. 


\title{
Neurology
}

\author{
Leukoaraiosis three-dimensional in Binswanger disease \\ Carlos Valencia, Joan Martí-Fàbregas, Jesús Pujol Nuez, et al. \\ Neurology 2001;56;610 \\ DOI 10.1212/WNL.56.5.610
}

\section{This information is current as of March 13, 2001}

\section{Updated Information \&} Services

References

Permissions \& Licensing

Reprints including high resolution figures, can be found at: http://n.neurology.org/content/56/5/610.full

This article cites 2 articles, 1 of which you can access for free at: http://n.neurology.org/content/56/5/610.full\#ref-list-1

Information about reproducing this article in parts (figures,tables) or in its entirety can be found online at:

http://www.neurology.org/about/about_the_journal\#permissions

Information about ordering reprints can be found online: http://n.neurology.org/subscribers/advertise

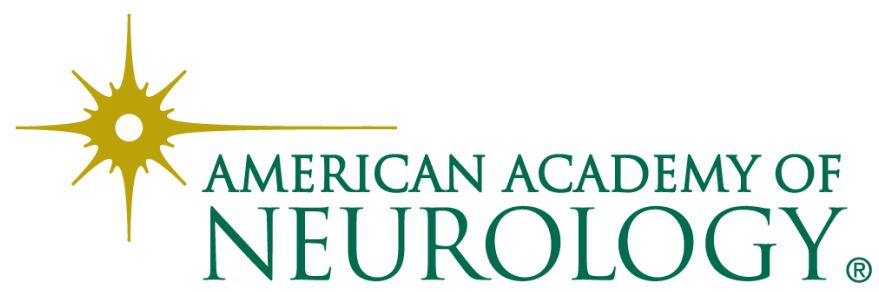

